\title{
Coat protein gene of a PStV-Bm isolate from West Nusa Tenggara, Indonesia
}

\author{
NUR INDAH JULISANIAH ${ }^{1,2, \boldsymbol{v}}$, SUHARJONO ${ }^{1}$, RETNO MASTUTI ${ }^{1}$, ESTRI LARAS ARUMINGTYAS $^{1}$ \\ ${ }^{1}$ Department of Biology, Faculty of Mathematics and Natural Sciences, Universitas Brawijaya. Jl. Veteran, Malang 65145, East Java, Indonesia \\ ${ }^{2}$ Department of Biology, Faculty of Mathematics and Natural Sciences, Universitas Mataram. Jl. Majapahit No. 62, Mataram 83125, West Nusa \\ Tenggara, Indonesia. Tel./fax.: +62-370-646506, `email: julisaniah@ gmail.com.
}

Manuscript received: 2 December 2019. Revision accepted: 6 February 2020.

\begin{abstract}
Julisaniah NI, Suharjono, Mastuti R, Arumingtyas EL. 2020. Coat protein gene of a PStV-Bm isolate from West Nusa Tenggara, Indonesia. Biodiversitas 21: 903-909. Peanut stripe virus (PStV) is a single-stranded positive-sense RNA virus capable of infecting peanut plants. An isolate of PStV (PStV-Bm) was collected from a peanut field in the Bima District, West Nusa Tenggara Province, Indonesia and the coat protein (CP) gene of this virus (CP-PStV) was extracted from the viral RNA and analyzed using reverse transcription-polymerase chain reaction methods. The CP-PStV gene of PStV-Bm was aligned with several PStV genes deposited in the Genbank (http://www.ncbi.nml.nih.gov). Based on the nucleotide sequence of the CP gene, PStV-Bm was grouped into a similar cluster with other PStVs that originated from Indonesia with a similar index, ranging from $96.8 \%$ to $98.9 \%$. Genetic similarity (about 96.1\%) was also observed between PStV-Bm and PStV from the USA. This genetic similarity indicated that viruses from adjacent regions have high genetic relationships. Some amino acid differences were observed in PStV-Bm that may be typical of this strain.
\end{abstract}

Keywords: Coat protein gene, Genetic relationship, Peanut stripe virus, West Nusa Tenggara

\section{INTRODUCTION}

Peanut stripe virus (PStV) is the causal agent of peanut stripe disease, a significant disease that reduces peanut yield (Sudarsono et al. 1997; Dang et al. 2010; Hou et al. 2011). PStV infection in peanut plants was first reported in the USA in 1984, but seed infection was first detected from China. The virus has spread to several countries, including China, Japan, Thailand, Philippines, and Indonesia (Saleh and Baliadi 1992; Demski et al. 1993; Suranto et al. 1997; Dang et al. 2010; Hou et al. 2011). In Indonesia, PStV was reported as infecting peanut plantations in several provinces (Saleh and Baliadi 1992; Akin et al. 1999; Saleh 2003), including West Nusa Tenggara.

PStV is classified into the Potyvirus genus (Potyviridae). It is a single-stranded RNA virus that encodes several proteins, such as protein $\mathrm{P} 1$, helper component-proteinase (HC-Pro), protein $\mathrm{P} 3$, protein $6 \mathrm{~K}$ (6K1), cytoplasmic inclusion (CI), 6K2, nuclear inclusion a (Nia), nuclear inclusion $\mathrm{b}$ and RNA-dependent RNA polymerase (NIb-Pol), and coat protein (CP; Gunasinghe et al. 1994; Higgins et al. 1998; Kim et al. 2003; Elmahdi and El Salam 2016).

Molecular detection and characterization of the plant virus have been achieved through reverse transcriptionpolymerase chain reactions (RT-PCR) using primers specific to a strain or group of the virus (Moreno et al. 2004; Adam et al. 2005; Massumi et al. 2009; Dang et al. 2010; Hou et al. 2011; Soumya et al. 2014). Among several genes in the virus, the $\mathrm{CP}$ gene is most often used for virus characterization (Suranto et al. 1998; Elmahdi and El
Salam 2016; Subiastuti et al. 2019). Indeed, in the Potyvirus genus, the best gene for characterization is the CP gene (Sukhla and Ward 1998; Urcuqui-Inchima et al. 2001; Hou et al. 2011; Silva et al. 2012; Beikzadeh et al. 2015). The CP gene of the virus plays several roles in the translation of viral RNA, such as targeting the viral genome to its site of replication, viral cell-to-cell movement, viral systemic movement, symptomatology of the infection, virulence, $\mathrm{R}$ gene-mediated host defense activation, suppressing RNA silencing, and determining the specificity of the virus transmission by vectors (Bol 2008; Hapsoro et al. 2008). According to Manzila et al. (2012), the genetic diversity of viruses can be distinguished based on the nucleotide or amino acid sequences of their $\mathrm{CP}$.

The CP-PStV gene must be sequenced for PStV characterization, the first step required for prevention efforts. The sequences of the $\mathrm{CP}$ gene of some PStV isolates from Indonesia have been reported. However, no studies have examined PStV from West Nusa Tenggara. Therefore, the nucleotide sequences of the $\mathrm{CP}$ gene of PStV-Bm, an isolate of PStV taken from Bima, West Nusa Tenggara, were determined in this research. The objective of this study was to analyze the nucleotide sequence of the $\mathrm{CP}$ gene of PStV-Bm.

\section{MATERIALS AND METHODS}

\section{Sampling}

Peanut leaves infected by PStV were taken from an infected peanut plant in a peanut field in Bima District, 
West Nusa Tenggara Province, Indonesia at approximately $37 \mathrm{~m}$ above sea level at the coordinate point $\mathrm{S} 08^{\circ} 33^{\prime} 45,1^{\prime \prime}$ and $\mathrm{E} 118^{\circ} 58^{\prime} 32,2^{\prime \prime}$. PStV infected peanut leaves in sampling area showed blotch symptoms. The infected peanut leaves were taken to a laboratory for molecular analysis.

\section{CP-PStV gene isolation}

The CP-PStV gene of PStV-Bm was amplified using a synthetic primer homologous to the NIb and 3'UTR gene, in which the CP gene is between NIb and 3'UTR. The gene was then sequenced. Analysis of CP-PStV was initiated by extracting the viral RNA using Geneaid Plant Virus RNA Extraction. To the infected leaves $(100 \mathrm{mg})$ were added 1 mL PVR buffer, $100 \mu \mathrm{L}$ PVRS buffer, and $10 \mu \mathrm{L} \beta$ mercaptoethanol in a microtube. The samples were ground well, then incubated at $70^{\circ} \mathrm{C}$ for 10 minutes. The sample suspension was centrifuged at the speed of $12,000 \mathrm{rpm}$ for 7 minutes. As much as $450 \mu \mathrm{L}$ of supernatant was transferred into the PV column, and $225 \mu \mathrm{L}$ of $96 \%$ ethanol was added. The suspension was then centrifuged at 12,000 rpm for 2 minutes. For RNA washing, $300 \mu \mathrm{L}$ buffer W1 was added to the PV column, then centrifuged at 12,000 rpm for 2 minutes. After discarding the flow-through, a 500 $\mu \mathrm{L}$ wash buffer was added and then centrifuged at 12,000 rpm for 2 minutes. For RNA elution, $50 \mu \mathrm{L}$ RNase-free water was added and centrifuged at 12,000 rpm for 2 minutes.

A superscript II cDNA synthesis kit (Invitrogen) was used for cDNA synthesis of the RNA samples. Amplification of the $\mathrm{CP}$ gene was performing using KAPPA RM HS $2 \mathrm{G}$ ready mix kit PCR, with specific primers for the CP-PStV gene: PST1 (5'GCATGCCCTCGCCATTGCAA3') and PST4 (5'TACATAGCAGAATCAGCACT3'; Akin and Sudarsono 2002). PCR amplification consisted of initiation at $95^{\circ} \mathrm{C}$ for 5 minutes, followed by 35 cycles of denaturation at $95^{\circ} \mathrm{C}$ for 1 minute, annealing at $57^{\circ} \mathrm{C}$ for 1 minute, and elongation at $72^{\circ} \mathrm{C}$ for 90 seconds. The extension of the $\mathrm{CP}$ gene was conducted at $72^{\circ} \mathrm{C}$ for 10 minutes. The amplicon of the CP-PStV gene was visualized using horizontal electrophoresis in $1.5 \%$ agarose gel with TBE (Tris Boric acid EDTA) as buffer running.

\section{Sequencing and PStV gene identification}

The amplicon of the PStV-Bm CP gene was sequenced in Firstbase, Malaysia. The sequences were aligned with reference sequences from GenBank (http://www.ncbi.nml.nih.gov). The following reference isolates were used from Indonesia: PStV I1 (\#AJ132146.1), PStV I2 (\#AJ132147.1), PStV I3 (\#AJ132148.1), PStV I5 (\#AJ132149.1), PStV I6 (\#AJ132150.1), PStV I7 (\#AJ132151.1), $\quad$ PStV I9 (\#AJ132152.1), PStV I10 (\#AJ132153.1), PStV I11 (\#AJ132154.1), PStV I12 (\#AJ132155.1), $\quad$ PStV I13 (\#AJ132156.1), PStV I14 (\#AJ132157.1), PStV I15 (\#AJ132158.1), and PStV Ib (\#Z21700.1). The following reference isolates were used from the USA: USA 1 (\#U34972), USA 2 (\#U05771), and USA 3 (X63559).

\section{Computer analysis}

The phylogenetic relationship of PStV was established using the neighbor-joining (NJ) method (Saitou and Nei 1987; Tamura et al. 2004). The percentage of replicate trees in which the associated taxa clustered together in the bootstrap test (1000 replicates) was shown next to the branches (Felsenstein 1985), and the phylogenetic tree was drawn using the NJ methods (Siatou and Nei 1987; Tamura et al. 2004). The analysis involved 18 CP-PStV genes that were conducted in MEGA7 software (Kumar et al. 2015). The CP-PStV genes were translated as amino acid sequences, and a comparison of the PStV proteins was conducted for evaluating the consequences of genetic variation. Analysis of the secondary structure of the protein was conducted using Discovery Studio software to determine the effect of genetic variation. The determination of secondary structure was done for analysis of functional protein.

\section{RESULTS AND DISCUSSION}

\section{CP-PstV gene from $\mathrm{BM}$ isolate}

The size of the PCR product using primer PST1 and PST4 was 1200 bp (Figure 1). This result was comparable to that of Akin and Sudarsono (2002), who reported that the length of the PCR product using primer PST4 and PST1 was $1.2 \mathrm{~kb}$ and consisted of NIb, CP, and 3'UTR. The sequence was in accordance with a nucleotide in GenBank (http://www.ncbi.nml.nih.gov), with $98 \%$ identity and $100 \%$ query cover to the PStV isolates of Indonesian origin (Table 1). This finding confirmed that the gene obtained was the CP-PStV gene.

The full length of the PStV genome consists of several genes (Demski et al. 1993; Kim et al. 2003). The length of the partial genome of PStV-Bm obtained in this study was 1071 bp (Figure 2). It consisted of part of NIb, the complete CP gene, and part of 3'UTR. The CP genes measuring $864 \mathrm{nt}$ were between NIb and 3'UTR (Figure 2). The CP gene consisted of $861 \mathrm{nt}$ translated codon and $3 \mathrm{nt}$ stop codon.

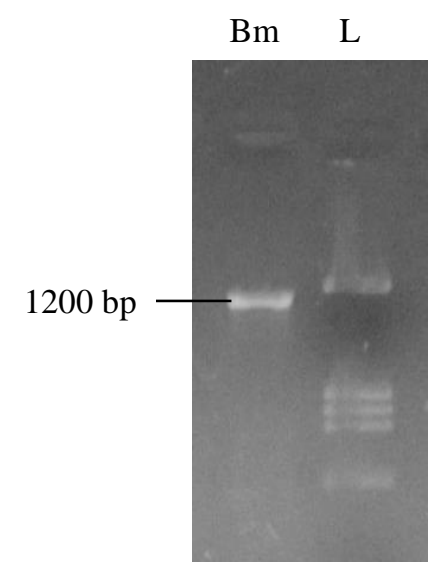

Figure 1. $1200 \mathrm{bp}$ of PCR product contains NIb, Coat Protein gene, 3'UTR of PStV. (Bm) PStV-Bm; (L) DNA Ladder 
Table 1. Identity (\%) of PStV-Bm with PStV references

\begin{tabular}{llc}
\hline \multicolumn{1}{c}{ PStV } & Accession no. & Identity (\%) \\
\hline PStV-I15 & AJ132158.1 & 98.9 \\
PStV-I14 & AJ132157.1 & 96.8 \\
PStV-I13 & AJ132156.1 & 98.9 \\
PStV-I12 & AJ132155.1 & 98.9 \\
PStV-I11 & AJ132154.1 & 98.9 \\
PStV-I10 & AJ132153.1 & 98.9 \\
PStV-I9 & AJ132152.1 & 98.9 \\
PStV-I7 & AJ132151.1 & 98.9 \\
PStV-I6 & AJ132150.1 & 98.9 \\
PStV-I5 & AJ132149.1 & 98.9 \\
PStV-I3 & AJ132148.1 & 98.9 \\
PStV-I2 & AJ132147.1 & 98.8 \\
PStV-I1 & AJ132146.1 & 98.8 \\
PStV-Ib & Z21700.1 & 97.1 \\
USA_1 & U34972 & 96.2 \\
USA_2 & U05771 & 96.3 \\
USA_3 & X63559 & 96.1 \\
\hline
\end{tabular}

\section{Clustering and comparison of CP-PStV gene from PStV-Bm}

The nucleotide analysis of $\mathrm{CP}$ of PStV-Bm showed the presence of multiple variations of nucleotides as compared with the reference isolates. The alignment results indicated a nucleotide change of the $\mathrm{Bm}$ CP-PStV gene at some base positions. A comparison of the nucleotide sequences of the CP-PStV gene of the Bm isolate with some PStV isolates in GenBank showed high similarities among the isolates (Table 2).

Based on the $\mathrm{CP}$ gene analysis in this study, PStV from Indonesia formed its own group, separate from PStV from the USA. This finding was in accordance with that of Higgins et al. (1998), who found that PStV from Indonesia is distinct from that from USA. The phylogeny tree based on nucleotide sequences of the CP gene using separate samples resulted in two main clades of PStV: the Indonesia clade and the USA clade. The phylogeny tree showed that PStV-Bm tends to be closely related to other PStVs from Indonesia (Figure 3).
PStV isolates in the first main clade were found in Indonesia, and PStV-Bm was in the same clade with other $\mathrm{PStV}$ isolates from Indonesia. The Indonesian clade was divided into two subclades. The first subclade was comprised of $13 \mathrm{PStV}$ isolates, including PStV-Bm, while the second subclade consisted of $2 \mathrm{PStV}$ isolates from Indonesia. The other $2 \mathrm{PStV}$ isolates from Indonesia were PStV-I4 and PStV-Ib. The second main clade was occupied by $3 \mathrm{PStV}$ isolates from the USA.

PStV-Bm was more closely related to the $12 \mathrm{PStV}$ isolates from Indonesia in the first group (with 98.9\% genetic similarity). The similarity value of PStV-Bm with Indonesian isolates in the second group was about $97 \%$. The lowest genetic similarity was found between PStV-Bm and the PStV USA isolates, at $96.1 \%$ (Table 2).

PStV-Bm obtained from West Nusa Tenggara, Indonesia, showed a high similarity with other isolates originating from Indonesia. This similarity indicates that relatedness among isolates tends to correlate with their geographic origin. The correlation between genetic relationships to geographic origin in a country is not always evident, but it can sometimes be seen at the continental level (Bateson et al. 2002; Noa-Carrazana et al. 2006). Phylogenetic analysis and genetic similarity value of the CP gene of PStV-Bm, other Indonesian PStV, and USA $\mathrm{PStV}$ suggested that PStV-Bm and other Indonesian PStV isolates found probably have a common ancestor.

A comparison of the amino acids of PStV also showed variability among this sample with other reference isolates (Fig. 3). Amino acid changes at some positions were also observed in the PStV-Bm isolate. Based on amino acid sequences alignment, some different amino acids occurred only in the PStV-Bm isolate. These were the amino acids at positions 23,38 , and 61 , respectively (Table 3 ).

Plant viruses have a distinctive amino acid motif that could be interpreted as having a good relationship between the vector and the plant host. A DAG (Asp-Ala-Gly) was observed in the amino acid sequence of PStV CP; this is a conserved motif because it is transmissible to an aphid as a vector (Shukla and Ward 1988; Higgins et al. 1998; Bol 2008). The DAG motif found in this study is shown in Figure 4.

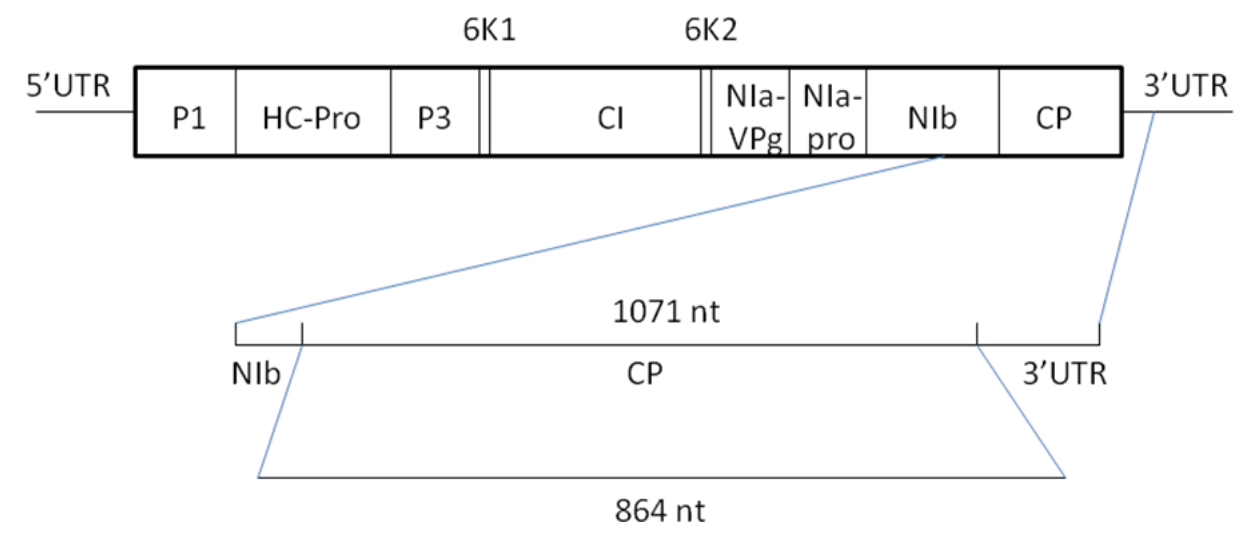

Figure 2. Schematic of PStV genome structure. The partial genome that was extracted in this study consisted of part of NIb, the complete CP gene, and part of 3'UTR. (Gunasinghe et al. 1994) 


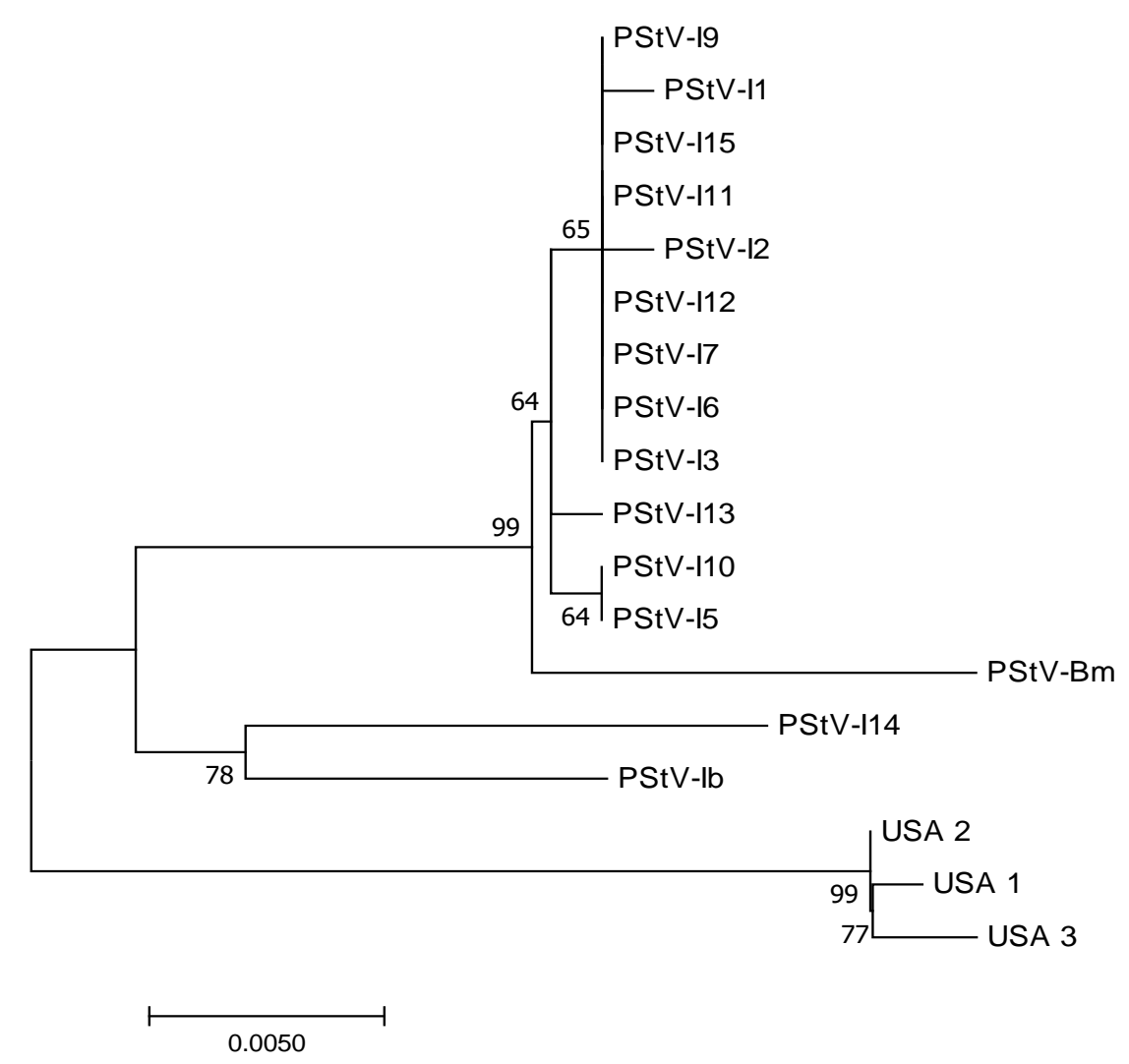

Figure 3. Phylogeny tree based on nucleotide sequences of the CP gene of PStV-Bm collected from West Nusa Tenggara, Indonesia, and some PStV isolates in GenBank. The dendrogram was constructed using MEGA7 software with 1000 bootstrap repeats using the neighbor-joining (NJ) algorithm

Table 2. Similarity (\%) of CP Gene of PStV-Bm with PStV Reference Isolates

\begin{tabular}{|c|c|c|c|c|c|c|c|c|c|c|c|c|c|c|c|c|c|c|c|}
\hline & & 1 & 2 & 3 & 4 & 5 & 6 & 7 & 8 & 9 & 10 & 11 & 12 & 13 & 14 & 15 & 16 & 17 & 18 \\
\hline 1 & PStV-Bm & & & & & & & & & & & & & & & & & & \\
\hline 2 & PStV-I15 & 98.9 & & & & & & & & & & & & & & & & & \\
\hline 3 & PStV-I14 & 96.8 & 97.7 & & & & & & & & & & & & & & & & \\
\hline 4 & PStV-I13 & 98.9 & 99.8 & 97.7 & & & & & & & & & & & & & & & \\
\hline 5 & PStV-I12 & 98.9 & 100.0 & 97.7 & 99.8 & & & & & & & & & & & & & & \\
\hline 6 & PStV-I11 & 98.9 & 100.0 & 97.7 & 99.8 & 100.0 & & & & & & & & & & & & & \\
\hline 7 & PStV-I10 & 98.9 & 99.8 & 97.7 & 99.8 & 99.8 & 99.8 & & & & & & & & & & & & \\
\hline 8 & PStV-I9 & 98.9 & 100.0 & 97.7 & 99.8 & 100.0 & 100.0 & 99.8 & & & & & & & & & & & \\
\hline 9 & PStV-I7 & 98.9 & 100.0 & 97.7 & 99.8 & 100.0 & 100.0 & 99.8 & 100.0 & & & & & & & & & & \\
\hline 10 & PStV-I6 & 98.9 & 100.0 & 97.7 & 99.8 & 100.0 & 100.0 & 99.8 & 100.0 & 100.0 & & & & & & & & & \\
\hline 11 & PStV-I5 & 98.9 & 99.8 & 97.7 & 99.8 & 99.8 & 99.8 & 100.0 & 99.8 & 99.8 & 99.8 & & & & & & & & \\
\hline 12 & PStV-I3 & 98.9 & 100.0 & 97.7 & 99.8 & 100.0 & 100.0 & 99.8 & 100.0 & 100.0 & 100.0 & 99.8 & & & & & & & \\
\hline 13 & PStV-I2 & 98.8 & 99.9 & 97.6 & 99.7 & 99.9 & 99.9 & 99.7 & 99.9 & 99.9 & 99.9 & 99.7 & 99.9 & & & & & & \\
\hline 14 & PStV-I1 & 98.8 & 99.9 & 97.6 & 99.7 & 99.9 & 99.9 & 99.7 & 99.9 & 99.9 & 99.9 & 99.7 & 99.9 & 99.8 & & & & & \\
\hline 15 & PStV-Ib & 97.1 & 98.0 & 98.1 & 98.0 & 98.0 & 98.0 & 98.0 & 98.0 & 98.0 & 98.0 & 98.0 & 98.0 & 97.9 & 97.9 & & & & \\
\hline 16 & USA-1 & 96.2 & 96.9 & 96.5 & 96.9 & 96.9 & 96.9 & 96.9 & 96.9 & 96.9 & 96.9 & 96.9 & 96.9 & 96.8 & 96.8 & 96.9 & & & \\
\hline 17 & USA-2 & 96.3 & 97.0 & 96.7 & 97.0 & 97.0 & 97.0 & 97.0 & 97.0 & 97.0 & 97.0 & 97.0 & 97.0 & 96.9 & 96.9 & 97.0 & 99.9 & & \\
\hline 18 & USA-3 & 96.1 & 96.8 & 96.4 & 96.8 & 96.8 & 96.8 & 96.8 & 96.8 & 96.8 & 96.8 & 96.8 & 96.8 & 96.7 & 96.7 & 96.8 & 99.7 & 99.8 & \\
\hline
\end{tabular}




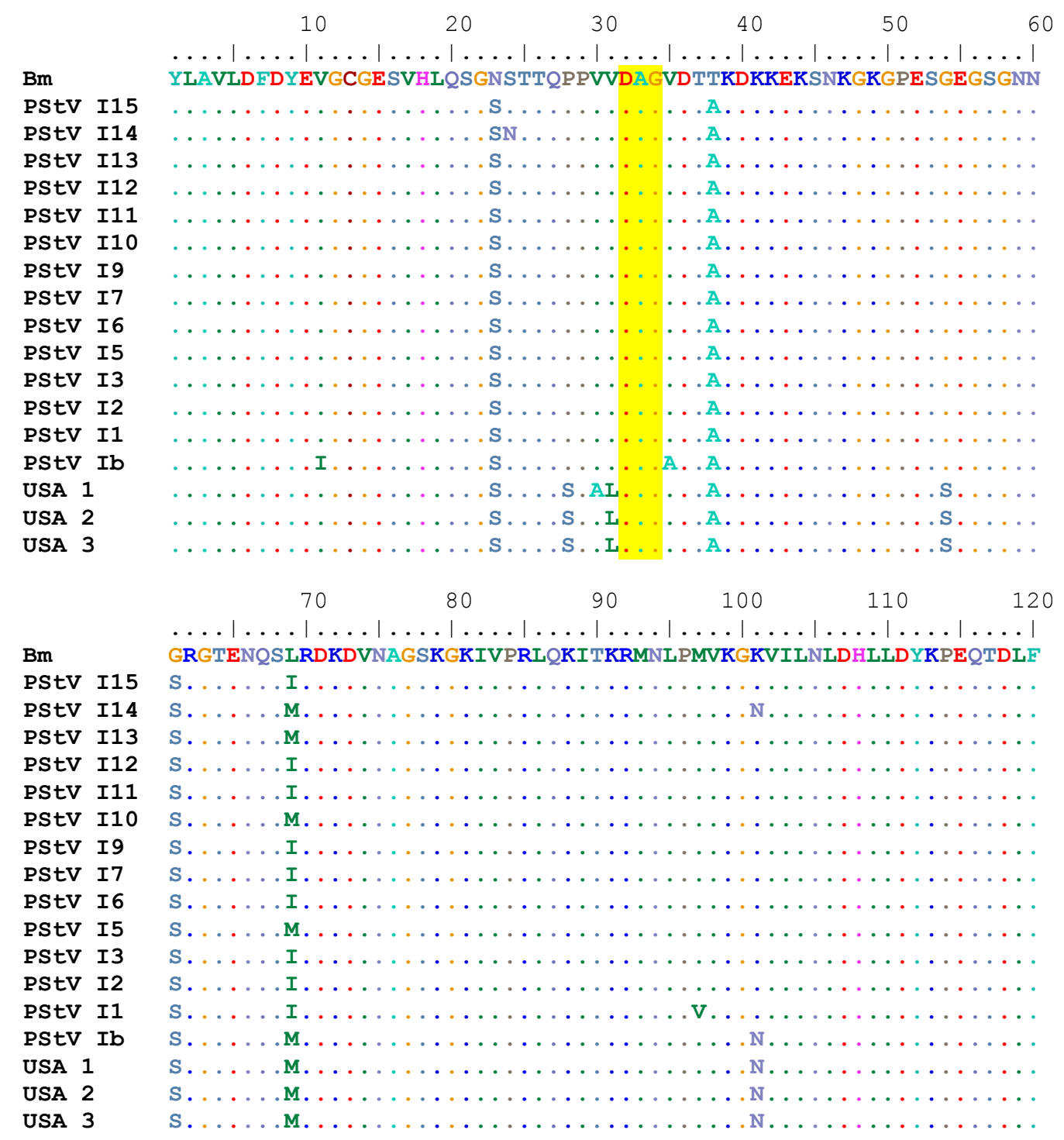

Figure 4. Comparison of amino acid sequences of the CP-PStV gene (1-120 AA). The yellow block shows the DAG motif

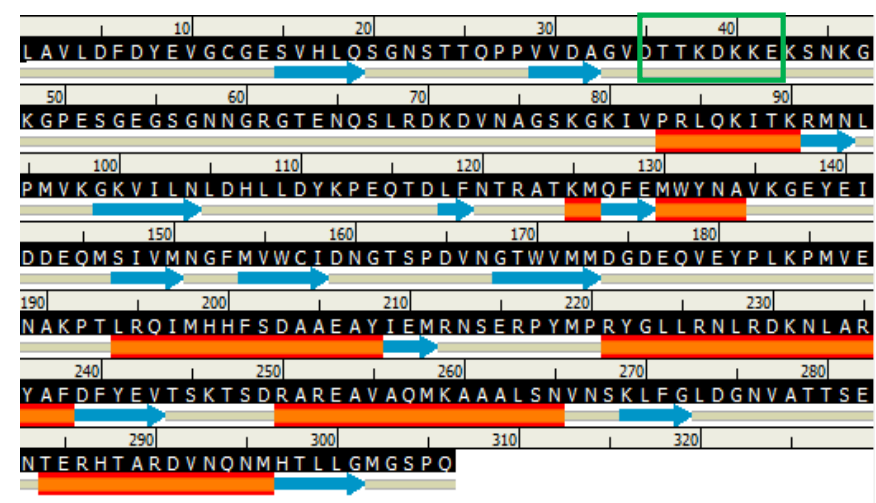

A

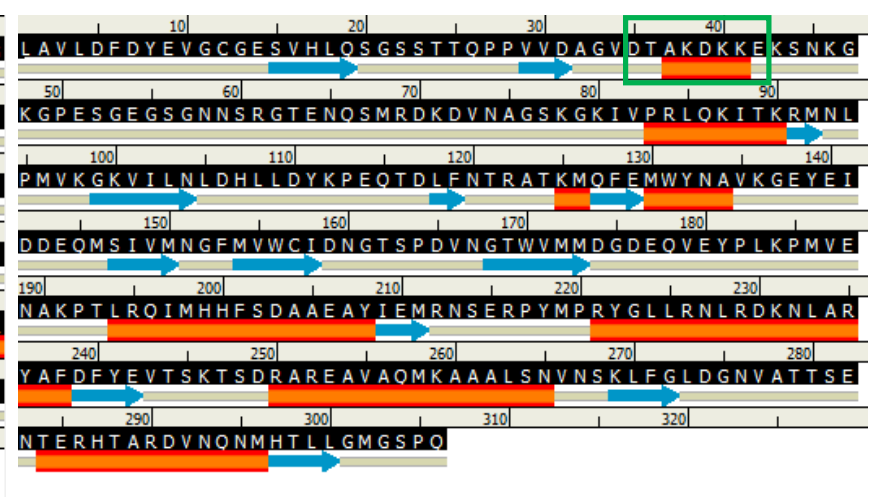

B

Figure 5. Secondary structure comparison of PStV gene. (A) PStV isolate Bm; (B) PStV isolate Indonesia I13. Blue arrows show betasheet structure, and orange blocks show alpha-helix structure. Green box shows the different secondary structure 
Table 3. Amino acid differences found only in $\mathrm{Bm}$

\begin{tabular}{llc}
\hline $\begin{array}{l}\text { Amino acid } \\
\text { position }\end{array}$ & $\begin{array}{c}\text { Base } \\
\text { differences }\end{array}$ & Amino acid differences \\
\hline 23 & $\mathrm{G} \rightarrow \mathrm{A}$ & $\mathrm{S} \rightarrow \mathrm{N}$ \\
38 & $\mathrm{G} \rightarrow \mathrm{A}$ & $\mathrm{A} \rightarrow \mathrm{T}$ \\
61 & $\mathrm{~A} \rightarrow \mathrm{G}$ & $\mathrm{S} \rightarrow \mathrm{G}$ \\
\hline
\end{tabular}

The close resemblance of the $\mathrm{CP}$ sequence of PStV-Bm to other Indonesian PStV strains rather than to the USA strains confirmed that the virus tended to be a strain of Indonesian PStV. Based on the amino acid sequences of the $\mathrm{CP}$ of this virus, the $\mathrm{N}$-terminal region was found to be the most variable. This phenomenon is a typical characteristic of $\mathrm{CP}$ regions also known for other members of Potyvirus, such as Johnsongrass mosaic virus (JGMV) and Sugarcane mosaic virus (SCMV) (Sukhla and ward 1988; Suranto et al. 1998). Meanwhile, the other two regions, core, and the C-terminals, did not appear as varied (Higgins et al. 1998; Pappu et al. 1998). Within the N-terminal region, at least 5 suspected mutations occurred, although all of the altered bases did not produce amino acid changes. Suranto et al. (1998) recorded that a change in 2 out of 5 bases results only in 3 different amino acids. These two silent mutations showed that mutation within the triplet codon of the amino acid was occurring, too. This indicates that although few bases change, this change may have been caused by the virulence of the virus strain. This variability of CP-PStV may determine the host specificity of the Potyvirus (Shukla and Ward 1988).

Another part of the 3'-region of CP-PStV was also sequenced, and hypervariability within the species of Potyvirus was also recorded from this virus strain. This portion was useful, especially for stabilizing the virus movement and infectivity. Complete sequencing of this 3 'translated region could possibly be used to disturb the gene function of the virus (Shukla and Ward 1988; Suranto et al. 1998; Kim et al. 2003).

The different amino acids in PStV CP affected the secondary structure of the protein, which appeared on the order of $38^{\text {th }}$ amino acids (Table 3 ). The difference between base $\mathrm{G}$ on GCC and A on ACC caused a difference in amino acid arrangement between alanine (A) and threonine (T). Based on the proteomic analysis, the amino acid difference between $\mathrm{A}$ and $\mathrm{T}$ caused the different secondary structure of the protein. The amino acid with $\mathrm{T}$ had a coil structure, while the amino acid with A had an alpha-helix structure (Fig. 4). These results indicated that the PStV-BM sample had a specific structure different from other isolates. Other amino acids found only in PStV-Bm were seen in amino acid positions 23 and 61, but these did not cause differences in protein structure.

Secondary structure has a crucial role in protein function. Changing this structure in a specific region can lead to the disruption of functional proteins, thus affecting the protein conformation based on the altered site (Schellman and Schellman 1997). The results showed that the CP-PStV gene had a different secondary structure in the region 37-41. The amino acid variation could change the coil structure to be a beta-sheet structure. Tyrosine, on the other hand, is a hydrophobic amino acid that is a component of $\mathrm{CP}$ protein from PStV-Bm (Lutke-Eversloh and Santos 2007). The amino acid variation was responsible for the specific structure differences among isolates, as the beta-sheet structure made protein more rigid than the coil structure. PStV isolates from Indonesia, particularly PStV-I13, may have had a more rigid CP protein structure than that of $\mathrm{CP}$ from $\mathrm{PStV}-\mathrm{Bm}$ due to the genetic variability of the $\mathrm{CP}$ protein. These results suggest that more PStV isolates from West Nusa Tenggara should be analyzed based on the $\mathrm{CP}$ sequence to determine the effect of the variability on virulence.

\section{ACKNOWLEDGEMENTS}

This article was part of research funded by the BPPDN scholarship, so the authors would like to thank the General of Higher Education of Indonesia. We also thank Prof. Suranto for reviewing this article.

\section{REFERENCES}

Adams MJ, Antoniw JF, Fauquet CM. 2005. Molecular criteria for genus and species discrimination within the family Potyviridae. Arc Virol 150 (3): 459-79.

Akin HM, Sudarsono, Rusmilah S. 1999. Variasi biologi dan molekuler strain-strain PStV yang diisolasi dari berbagai lokasi penanaman kacang tanah di Indonesia. Buletin Hama dan Penyakit Tumbuhan 11 (2): 56-61. [Indonesian]

Akin HM, Sudarsono. 2002. Variasi genetika galur peanut stripe potyvirus dan hubungan evolusinya dengan subkelompok bean common mosaic virus. Jurnal Hayati 9 (1): 5-9. [Indonesian]

Bateson MF, Lines RE, Revill P, Chaleeprom W, Ha CV, Gibbs AJ, Dale JL. 2002. On the evolution and molecular epidemiology of the potyvirus papaya ringspot virus. J Gen virol 83: 2575-2585.

Beikzadeh N, Hassani-Mehraban A, Peters D. 2015. Molecular identification of an isolate of peanut mottle virus (PeMoV) in Iran. J Agr Sci Technol 17: 765-776.

Bol JF. 2008. Plant Virology Protocols: From Viral Sequence to Protein Function. Humana Press, Totowa, NJ.

Dang PM, Scully BT, Lamb MC, Guo BZ. 2010. Analysis and RT-PCR identification of viral sequences in Peanut (Arachis hypogaea L.) expressed sequence tags from different Peanut tissues. J Plant Pathol 9 (10): 14-22.

Demski JW, Reddy DVR, Wongkaew S, Xu ZY, Khun CW, Cassidy BG, Shukla DD, Middleton KJ, Sreenivasulu P, Prasada Rao RDVJ, Senboku T, Dollet M, McDonald D. 1993. Peanut stripe Virus. International Crops Reseach Institute for the Semi-Arid Tropics, India.

Elmahdy H, El Salam SA. 2016. Nucleotide and amino acid sequencing of a coat protein of an Egyptian isolate of potato virus Y (PVY). Asian J Appl Sci 4 (2): 348-362.

Felsenstein J. 1985. Confidence limits on phylogenies: An approach using the bootstrap. Evolution 39: 783-791.

Gunasinghe UB, Flasinski S, Nelson RS, Cassidy BG. 1994. Nucleotide sequence and genome organization of peanut stripe virus. J Gen Virol 75: 2519-2526.

Hapsoro D, Aswidinnoor H, Suseno R, Jumanto, Sudarsono. 2008. Inheritance of resistance to $\mathrm{PStV}$ in transgenic peanuts containing $\mathrm{cp}$ PStV Gene. J HPT Tropika 8 (1): 31-38. [Indonesian]

Higgins CM, Cassidy BG, Teycheney PY, Wongkaew S, Dietzgen RG. 1998. Sequences of the coat protein gene of five peanut stripe virus (PStV) strain from Thailand and their evolutionary relationship with 
other beans common mosaic virus sequences. J Arch Virol 143: 1655 1667.

Hou SS, Chi YC, Liu YY, Li XD, Yu SL, Li XD. 2011. Molecular analysis of the coat protein gene of peanut stripe virus from China. J Acta Virol 55: 123-129.

Kim KS, Oh HY, Suranto S, Nurhayati E, Gough KH, Shukla DD, Pallaghy CK. 2003. Infectivity of in vitro transcripts of Johnsongrass mosaic potyvirus full-length cDNA clones in maize and sorghum. Arch Virol 148: 563-574.

Kumar S, Stecher G, Tamura K. 2015. MEGA7: Molecular evolutionary genetics analysis version 7.0 for bigger datasets. Mol Biol Evol 33 (7):1870-4

Lutke-Eversloh T, Santos CN. 2007. Perspectives of biotechnological production of L-tyrosine and its applications. J Appl Microbiol Biotechnol 77 (4): 751-762.

Manzila I, Hidayat SH, Mariska I, Sujiprihati S. 2012. Analisis gen selubung protein chili veinal mottle potyvirus dari beberapa daerah di Indonesia. Journal AgroBiogen 8 (1): 27-37. [Indonesian]

Massumi H, Shaabanian M, Pour AH, Heydarnejad J, Rahimian H. 2009. Incidence of viruses infecting tomato and their natural hosts in the Southeast and central regions of Iran. J Plant Dis 93: 67-72

Moreno IM, Malpica JM, Di'az-Pendón JA, Moriones E, Fraile A, Garc1'a-Arenal F. 2004. Variability and genetic structure of the population of watermelon mosaic virus infecting melon in Spain. $\mathrm{J}$ Virol 318: 451- 460.

Noa-Carrazana JC, Gonzalez-de-leon D, Ruiz-Castro BS, Pinero D, SilvaRosales L. 2006. Distribution of papaya ringspot virus and papaya mosaic virus in papaya plants (Carica papaya) in Mexico. J Plant Dis 90 (8): 1004-1011.

Pappu H, Pappu S, Jain R, Bertrand, P, Culbreath, A, McPherson R, Csinos A. 1998. Sequence characteristics of natural populations of tomato spotted wilt tospovirus infecting flue-cured tobacco in Georgia. Virus Genes 17: 169-177.
Saitou N, Nei M. 1987. The neighbor-joining method: A new method for reconstructing phylogenetic trees. Mol Biol Evol 4:406-425.

Saleh N, Baliadi Y. 1992. Penyakit virus belang kacang tanah (Peanut Stripe Virus) dan usaha pengendaliannya. Monograf Balitkabi 13: 306-328. [Indonesian]

Saleh N. 2003. Ekobiologi dan optimalisasi pengendalian penyakit belang pada kacang tanah melalui pengelolaan tanaman secara terpadu. Jurnal litbang pertanian 22 (2): 41-48. [Indonesian]

Schellman JA, Schellman CG. 1997. Kaj Ulrik Linderstrøm-Lang (18961959). Protein Sci 6 (5): 1092-100.

Shukla DD, Ward CW. 1988. Amino acid sequence homology of coat protein as a basis for identification and classification of the potyvirus group. J Gen Virol 69: 2703-2710.

Silva SJC, Castillo-Urquiza GP, Hora-Junior BT, Assuncao IP, Lima GSA, Pio-Ribeiro G, Mizubuti ESG, Zerbini FM. 2012. Species diversity, phylogeny and genetic variability of begomovirus populations infecting leguminous weeds in northeastern Brazil. J Plant Pathol 6: 457-467

Soumya K, Yogita M, Prasanthi Y, Anitha K, Kishor PB, Jain RK, Mandal B. 2014. Molecular characterization of Indian isolate of peanut mottle virus and immunodiagnosis using bacterial expressed core capsid protein. J Virus Dis 25 (3): 331-337.

Subiastuti AS, Hartono S, Daryono BS. 2019. Detection and identification of Begomovirus infecting Cucurbitaceae and Solanaceae in Yogyakarta, Indonesia. Biodiversitas 20 (3): 738-744

Suranto, Gough KH, Shukla DD, Pallaghy CK. 1998. Coat protein sequence of Kris-infecting strain of Johnsongrass mosaic potyvirus. J Arch Virol 143: 1015-1020

Tamura K, Nei M, Kumar S. 2004. Prospects for inferring very large phylogenies by using the neighbor-joining method. Proc Natl Acad Sci USA 101 (30): 11030-11035.

Urcuqui-Inchima S, Haenni AL, Bernardi F. 2001. Potyvirus proteins: a wealth of functions. J Virus Res 74: 157-175. 